\title{
PENGARUH PERBANDINGAN NACL DAN COPPER SULPHATE TERHADAP MATERIAL HILANG PADA PERENDAMAN LOGAM ST41
}

\author{
Eko Budi Santoso ${ }^{1}$, Achmad Taufik ${ }^{2}$, Eva Hertnacahyani Herraprastanti ${ }^{3}$ \\ 1,2 Teknik Mesin , Institut Teknologi Nasional Malang \\ ${ }^{3}$ Teknik Mesin , STT Ronggolawe Cepu
}

Email : azizankoe@gmail.com¹, ach_taufik@lecturer.itn.ac.id ${ }^{2}$,ev.hertna@gmail.com³

\begin{abstract}
Abstrak
Dalam menghadapi kemajuan pada era industrialisasi maka ilmu pengetahuan dan teknologi yang berhubungan dengan proses perlindungan dari pengikisian logam oleh material lain atau yang dikenal dengan korosi juga mengalami perkembangan yang pesat. Banyak cara yang dilakukan antara lain dengan pelumasan dan pelapisan, dimana tujuannya adalah mencegah lajunya korosi atau pengikisan yang akan menurunkan sifat terbaik material. Korosi dianggap sebagai suatu kerugian dalam mempertahankan mechanical properties dari suatu material, tetapi masih ada peluang yang bisa dilakukan dengan memanfaatkan korosi. Dalam penelitian ini bertujuan untuk mengetahui pengaruh perbandingan massa antara larutan $\mathrm{NaCl}$ dan Cooper Sulphate terhadap material yang hilang pada logam ST 41. Spesimen direndam dengan variasi perbandingan massa antara larutan $\mathrm{NaCl}$ dengan Copper Sulphate dengan menggunakan variasi perbandingan antara $\mathrm{NaCl}$ dan Copper Sulphate, dengan waktu perendaman adalah 6 jam, 12 jam dan 18 jam. Untuk mengetahui material hilang dilakukan dengan melakukan penimbangan, pengukuran $\mathrm{pH}$ dan pengamatan visual hasil perendaman. Dari Penelitian ini didapatkan hasil material hilang paling kecil di dapatkan pada hasil perendaman dengan perbandingan 1:1 dengan material hilang rata rata 0,0025 gr, sedang material hilang terbesar di dapat pada perbandingan 1:3 yaitu sebesar rata rata 0,0235 gram. Secara Visual kekasaran permukaan material yang dikenai perlakuan dimana perbandingan Cooper Sulphate lebih besar, terlihat lebih kasar di banding dengan yang lainnya
\end{abstract}

Kata kunci: Korosi, Baja ST 41, NaCl, Copper Sulphate

\begin{abstract}
In facing the advancement of the industrialization era, science and technology related to the protection process from metal erosion by other materials or known as corrosion, also experienced rapid development. Many ways are done, among others, by lubrication and coating, which aims to prevent the corrosion rate which will reduce the best properties of the material. Corrosion is considered as a loss in maintaining the mechanical properties of a material, but there is still a possibility that it can be done by utilizing corrosion. This study aims to determine the effect of the mass ratio between the $\mathrm{NaCl}$ and Cooper Sulfate solutions on the lost material in ST 41 metal. The specimens were immersed with various mass ratios between $\mathrm{NaCl}$ and Copper Sulfate solutions using variations in the ratio between $\mathrm{NaCl}$ and Copper Sulfate, with immersion times of 6 hours, 12 hours and 18 hours. To find out the missing material, it is done by weighing, measuring the $\mathrm{pH}$ and visual observation of the immersion results. From this research, it was found that the smallest loss of material was obtained in the immersion results with a ratio of 1:1 with an average loss of material of
\end{abstract}


0.0025 grams, while the largest loss of material was obtained at a ratio of 1:3. namely 0.0235 grams Visually the surface roughness Materials that are subjected to treatment in which the Cooper Sulfate ratio is greater, look rougher than others.

Keywords : corrosion, Steel ST41, $\mathrm{NaCl}$, Copper Sulphate

\section{PENDAHULUAN}

Perkembangan teknologi industri, membawa dampak ditemukannya material material baru yang mempunyai karakteristik tertentu. Material baru yang banyak diteliti adalah material non logam. Hal ini dikarenakan sumber daya alam sebagai bahan dari material logam sudah sangat menipis jumlahnya. Namun demikian untuk material logam juga masih banyak di gunakan di industri besar maupun kecil. Salah satu faktor yang mempengaruhi terhadap daya tahan logam dalam mempertahankan sifat terbaiknya adalah faktor lingkungan. Lingkungan bisa bersifat asam, basa ataupun normal. Indonesia merupakan negara yang beriklim tropis dengan tingkat curah hujan dan kelembaban yang tinggi serta intensitas sinar matahari yang tinggi pula, dan sebagai negara berkembang, di Indonesia juga banyak bermunculan industri-industri yang mempunyai pengaruh cukup besar terhadap tingkat pencemaran pada lingkungan. Fenomena alam dan material khususnya logam mempunyai suatu keterikatan dalam suatu sistem dan proses. Hubungan tersebut diimplementasikan dalam suatu proses kerusakan yang dinamakan korosi.

Penurunan kualitas dan kerugian materil salah satunya diakibatkan oleh korosi. Korosi adalah kerusakan fisik dari material akibat reaksi dengan lingkungan sekitarnya. Korosi akan menyebabkan penurunaan kualitas yang disebabkan oleh reaksi kimia bahan logam dengan unsur lain. Terdapat dua jenis mekanisma utama dari korosi yaitu berdasarkan reaksi kimia secara langsung dan reaksi elektrokimia. Korosi dapat terjadi didalam lingkungan kering dan juga lingkungan basah. Korosi pada logam hanya dapat dicegah dan dikendalikan tapi tidak dapat dihindari sehingga masa pakai yang lebih lama. Efek kerusakan produk korosi antara lain berbagai macam oksida logam, kerusakan permukaan logam secara morfologi, perubahaan sifat mekanis, perubahan sifat kimia. Berdasar pengetahuan tentang elektrokimia proses korosi, dapat dilakukan usaha-usaha untuk pencegahan terjadinya korosi. Usaha usaha untuk melindungi dari kerusakan khususnya kerusakan karena korosi cara yang banyak dilakukan dengan pelapisan menggunakan cat, dengan pertimbangan adalah biaya yang sangat murah di banding dengan cara cara lainnya. Usaha lain sebagai upaya melindungi logam dari korosi adalah dengan penerapan prinsip elektroplating. Elektroplating merupakan suatu cara pelapisan logam dengan menggunakan arus listrik. Dalam elektro kimia energi listrik diubah menjadi energi kimia dalam sel elektrolitik. Dalam elektroplating digunakan logam yang lebih tahan korosi digunakan untuk melapisi logam yang mudah berkarat seperti Besi. Secara elektrokimia, logam

Telah dilakukan penelitian untuk menentukan kecepatan korosi yang disebabkan oleh tiga bahan oksidan yaitu air, asam dan garam terhadap logam (plat besi). Waktu pengamatan dilakukan secara berselang, yakni $\mathrm{t}=0,5,10,15,20$ dan 25 hari. Dengan menggunakan sinar Gamma $(\gamma)$ yang dihasilkan dari sumber Cobalt (Co60) yang diradiasikan pada plat logam, kemudian radiasi sinar $\gamma$ dideteksi oleh tabung Geiger Muller. Intensitas cacahan 
menunjukkan daya tembus sinar $\gamma$ semakin tinggi pada logam yang teroksidasi dengan waktu yang lebih lama. Hal ini memberi arti terjadi kerenggangan molekul besi, kerenggangan tersebut akibat proses oksidasi (korosi). Hasil penelitian menunjukkan bahwa daya serap sinar $\gamma$ dalam material merupakan fungsi eksponensial terhadap waktu. Kecepatan korosi yang didapatkan adalah untuk asam sulfat $=-0.0056 \mathrm{~dB} /$ hari, garam $=-0.0053$ $\mathrm{dB} /$ hari, dan air $=-0.0047 \mathrm{~dB} /$ hari.

Disamping sebagai bentuk kerugian terhadap material, korosi atau pengikisan material juga bisa dimanfaatkan untuk keperluan industri , khususnya industri kecil. Pemanfaatan tersebut diantaranya adalah untuk memberikan tanda atau gambar pada hasil produksi dengan perlakuan tertentu. Dalam penelitian ini akan dilakukan penelitian dengan judul Pengaruh Perbandingan $\mathrm{NaCl}$ Dan Copper Sulphate Terhadap Material Hilang Pada Logam Mild Steel ST 41.

\section{METODE PELAKSANAAN}

Pada penelitian ini menggunakan metode true experimental research,ditunjang dengan data dan informasi yang diperoleh melalui studi pustaka dari buku dan jurnal penelitian yang ada.

Tahapan dalam penelitian ini adalah :

Jenis variabel dalam penelitian dapat dilihat pada skema berikut ini :

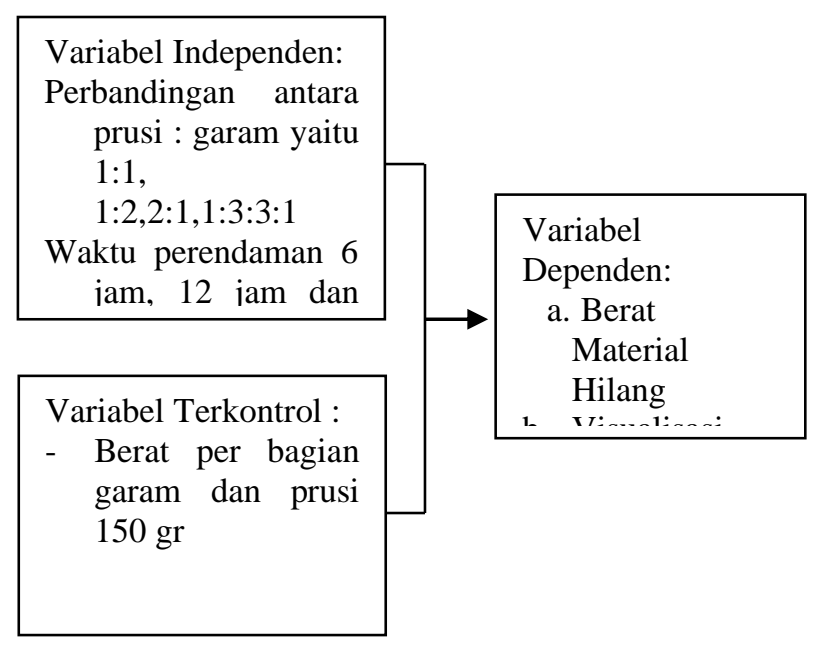

Sedang flow cart yang digunakan dalam penelitian ini adalah sebagai berikut :

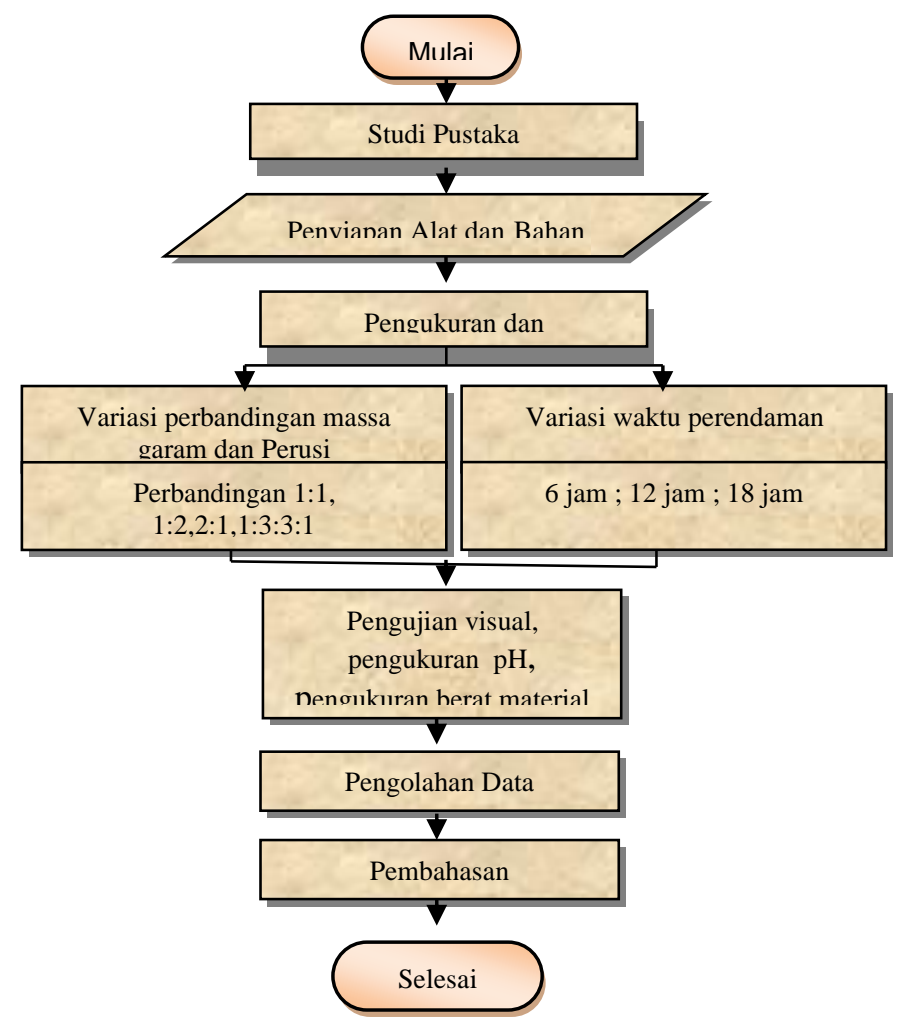

\section{Material}

Baja rendah karbon ST41 memiliki kemampuan las yang sangat baik dan dapat menghasilkan bentuk yang seragam dan keras dan dianggap sebagai baja terbaik untuk bagian karburasi. Baja ringan atau rendah karbon ST41 menawarkan keseimbangan yang baik antara kekerasan, kekuatan dan elastisitas. Dengan karakteristik mekanis yang lebih tinggi, gulungan panas baja ST41 juga memiliki karakteristik permesinan dan kekerasan Brinell yang telah ditingkatkan. Kontrol spesifikasi pabrik digunakan untuk persiapan awal, komposisi kimia, proses penggulungan dan pemanasan. Semua proses ini mengembangkan produk dengan kualitas terbaik yang sesuai untuk proses fabrikasi seperti pengelasan, pengeboran, permesinan, pendinginan dan pemanasan. Spesifikasi material ini sangat beragam dari mulai JIS G3131 SPHC, JIS G3101 SS400 dan ASTM A36 ketiga spesifikasi tersebut yang paling dominan dipasaran. Baik 
produk lokal KS, GG dan Import . Ketebalan yang tersedia dari mulai $1,2 \mathrm{~mm}$ sampai dengan $200 \mathrm{~mm}$.

Tabel 1. Komposisi Kimia Material ST 41 (\% berat)

\begin{tabular}{c|c|c|c}
$\mathbf{C}$ & 0.02 & $\mathbf{S i}$ & 0.4 \\
\hline $\mathbf{M n}$ & $0.80-1.40$ & $\mathbf{P}$ & 0.025 \\
\hline $\mathbf{S}$ & 0.015 & $\mathbf{A L}$ & 0.02 \\
\hline $\mathbf{N}$ & 0.012 & $\mathbf{C r}$ & 0.3 \\
\hline $\mathbf{C u}$ & 0.3 & $\mathbf{M o}$ & 0.08 \\
\hline $\mathbf{N b}$ & 0.02 & $\mathbf{N i}$ & 0.3 \\
\hline $\mathbf{T i}$ & 0.03 & $\mathbf{V i}$ & 0.02
\end{tabular}

Dalam pembuatan spesimen , material awal berbentuk plate strip kemudian di potong dengan menggunakan hack saw untuk di buat menjadi ukuran 48 × $25 \times 2 \mathrm{~mm}$. Kemudian dari hasil pemotongan dilakukan pengeringan di bawah sinar matahari untuk memastikan bahwa tidak ada air atau uap air yang menempel pada spesimen. Spesimen kemudian sebagian di tutup dengan isolasi dengan tujuan untuk melindungi permukaan agar tidak terkena cat, jadi bagian yang di tutup isolasi yang akan mendapat perlakuan dalam penelitian ini. Setelah di cat kemudian bagian yang ditutup isolasi dibuka kembali . Selanjutnya dilakukan penimbangan dan pencatatan .

Kemudian di siapkan larutan $\mathrm{NaCl}$ dan Copper Sulphate dengan masing masing perbandingan yang sudah di tentukan dan di ukur $\mathrm{pH}$, kemudian masing masing spesimen direndam dengan waktu masing masing 6 jam, 12 jam dan 18 jam , kemudian diangkat dan dilakukan pengamatan visual yang selanjutnya dibersihkan, kemudian di keringkan dan dilakukan penimbangan dan pencatatan. $\mathrm{pH}$ larutan setelah perlakuan juga dilakukan pengukuran dan pencatatan. Dari data yang didapat kemudian dianalisa dan di olah dengan menggunakan software Anova.

\section{HASIL DAN PEMBAHASAN}

Dari metode penelitian yang telah ditentukan yaitu true experimental, pada
Gambar 1 adalah gambar rangkaian prosen dalam penelitian ini . Pada Gambar 1a, adalah persiapan spesimen yang meliputi pemotongan , pengeringan, penutupan permukaan, pengecatan , pembukaan kembali permukaan yang ditutup dan pengeringan spesimen, selanjutnya pada gambar 1b, setiap spesimen di lakukan penimbangan untuk mengetahui berat awal sebelum perlakuan dan gambar 1c pada waktu dilakukan perendaman juga dilakukan pengukuran $\mathrm{pH}$ larutan.

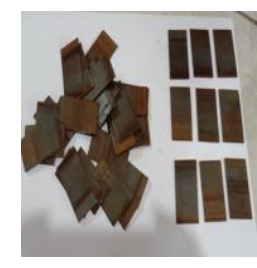

a

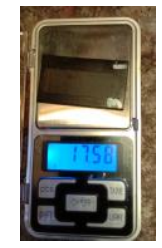

b

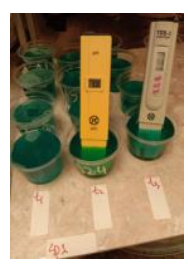

c
Gambar 1,

Rangkaian proses penelitian a) Spesimen uji , b) Penimbangan Spesimen c) perendaman dan pengukuran $\mathrm{pH}$

Dari penelitian yang telah dilakukan , yaitu proses perendaman spesimen dengan variasi perbandingan massa dan waktu menghasilkan data dalam tabel 2 sebagai berikut :

Tabel 2. Data Hasil Pengujian

\begin{tabular}{|c|c|c|c|c|c|c|}
\hline $\begin{array}{c}\text { Perban } \\
\text { dingan } \\
\text { NaCl : } \\
\text { Copper } \\
\text { Sulphat } \\
\text { e } \\
\end{array}$ & $\begin{array}{c}\text { Kod } \\
\text { e } \\
\text { spesi } \\
\text { men }\end{array}$ & $\begin{array}{c}\text { Be } \\
\text { rat } \\
\text { hil } \\
\text { an } \\
\text { g } \\
\text { t1 } \\
=6 \\
\text { ja } \\
\text { m }\end{array}$ & $\begin{array}{l}\text { Kod } \\
\text { e } \\
\text { spesi } \\
\text { men }\end{array}$ & $\begin{array}{c}\text { Be } \\
\text { rat } \\
\text { hil } \\
\text { an } \\
\text { g } \\
\text { t2 } \\
= \\
12 \\
\text { ja } \\
\text { m }\end{array}$ & $\begin{array}{l}\text { Kod } \\
\text { e } \\
\text { spesi } \\
\text { men }\end{array}$ & $\begin{array}{c}\text { Be } \\
\text { rat } \\
\text { hil } \\
\text { an } \\
\text { g } \\
\text { t3 } \\
= \\
18 \\
\text { ja } \\
\text { m }\end{array}$ \\
\hline \multirow{4}{*}{$1: 1$} & 1.1 & 0 & 1.5 & 0 & 1.9 & 0 \\
\hline & 1.2 & $\begin{array}{c}0.0 \\
1\end{array}$ & 1.6 & 0 & 1.10 & $\begin{array}{c}0.0 \\
3\end{array}$ \\
\hline & 1.3 & 0 & 1.7 & $\begin{array}{c}0.0 \\
1 \\
\end{array}$ & 1.11 & $\begin{array}{c}0.0 \\
1 \\
\end{array}$ \\
\hline & 1.4 & 0 & 1.8 & 0 & 1.12 & 0.0 \\
\hline
\end{tabular}




\begin{tabular}{|c|c|c|c|c|c|c|}
\hline & & & & & & 1 \\
\hline \multirow{4}{*}{$1: 2$} & 2.1 & $\begin{array}{c}0.0 \\
1\end{array}$ & 2.5 & $\begin{array}{c}0.0 \\
2 \\
\end{array}$ & 2.9 & $\begin{array}{c}0.0 \\
1 \\
\end{array}$ \\
\hline & 2.2 & $\begin{array}{c}0.0 \\
2\end{array}$ & 2.6 & $\begin{array}{c}0.0 \\
1 \\
\end{array}$ & 2.10 & $\begin{array}{c}0.0 \\
1\end{array}$ \\
\hline & 2.3 & $\begin{array}{c}0.0 \\
1 \\
\end{array}$ & 2.7 & $\begin{array}{c}0.0 \\
2\end{array}$ & 2.11 & $\begin{array}{c}0.0 \\
2\end{array}$ \\
\hline & 2.4 & 0 & 2.8 & 0 & 2.12 & $\begin{array}{c}0.0 \\
4\end{array}$ \\
\hline \multirow{4}{*}{$2: 1$} & 3.1 & $\begin{array}{c}0.0 \\
3\end{array}$ & 3.5 & $\begin{array}{c}0.0 \\
8\end{array}$ & 3.9 & $\begin{array}{c}0.1 \\
4\end{array}$ \\
\hline & 3.2 & $\begin{array}{c}0.0 \\
2\end{array}$ & 3.6 & $\begin{array}{c}0.0 \\
7 \\
\end{array}$ & 3.10 & $\begin{array}{c}0.1 \\
3\end{array}$ \\
\hline & 3.3 & $\begin{array}{c}0.0 \\
4 \\
\end{array}$ & 3.7 & $\begin{array}{c}0.0 \\
8 \\
\end{array}$ & 3.11 & $\begin{array}{c}0.1 \\
4\end{array}$ \\
\hline & 3.4 & $\begin{array}{c}0.0 \\
2 \\
\end{array}$ & 3.8 & $\begin{array}{c}0.0 \\
7 \\
\end{array}$ & 3.12 & $\begin{array}{c}0.1 \\
5\end{array}$ \\
\hline \multirow{4}{*}{$1: 3$} & 4.1 & 0 & 4.5 & $\begin{array}{c}0.0 \\
3\end{array}$ & 4.9 & $\begin{array}{c}0.0 \\
6\end{array}$ \\
\hline & 4.2 & $\begin{array}{c}0.0 \\
2\end{array}$ & 4.6 & $\begin{array}{c}0.0 \\
7 \\
\end{array}$ & 4.10 & $\begin{array}{c}0.0 \\
7\end{array}$ \\
\hline & 4.3 & $\begin{array}{c}0.0 \\
4\end{array}$ & 4.7 & $\begin{array}{c}0.0 \\
3\end{array}$ & 4.11 & $\begin{array}{c}0.0 \\
4\end{array}$ \\
\hline & 4.4 & $\begin{array}{c}0.0 \\
3\end{array}$ & 4.8 & $\begin{array}{c}0.0 \\
6\end{array}$ & 4.12 & $\begin{array}{c}0.0 \\
7 \\
\end{array}$ \\
\hline \multirow{4}{*}{$3: 1$} & 5.1 & $\begin{array}{c}0.0 \\
7 \\
\end{array}$ & 5.5 & $\begin{array}{c}0.1 \\
2 \\
\end{array}$ & 5.9 & $\begin{array}{c}0.2 \\
4\end{array}$ \\
\hline & 5.2 & $\begin{array}{c}0.0 \\
7\end{array}$ & 5.6 & $\begin{array}{c}0.1 \\
4\end{array}$ & 5.10 & $\begin{array}{c}0.2 \\
3\end{array}$ \\
\hline & 5.3 & $\begin{array}{c}0.0 \\
6\end{array}$ & 5.7 & $\begin{array}{c}0.1 \\
1\end{array}$ & 5.11 & $\begin{array}{c}0.2 \\
1\end{array}$ \\
\hline & 5.4 & $\begin{array}{c}0.0 \\
5\end{array}$ & 5.8 & $\begin{array}{c}0.0 \\
9\end{array}$ & 5.12 & $\begin{array}{c}0.2 \\
6\end{array}$ \\
\hline
\end{tabular}

Berdasarkan hasil pengujian bisa diketahui pengaruh perendaman larutan $\mathrm{NaCl}$ dan Larutan Copper sulphate terhadap spesimen .

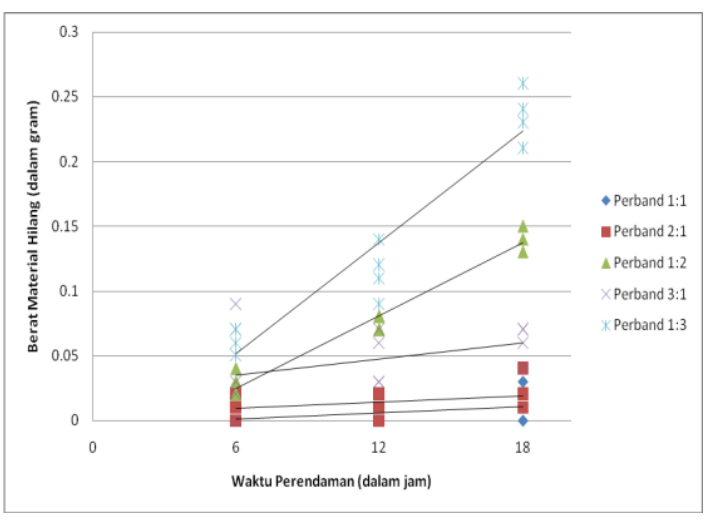

Gambar 2,
Grafik Hubungan antara perbandingan massa larutan, waktu perendaman dan berat material hilang

Dari gambar 2 , perbandingan 1 didapatkan hasil material hilang terbesar adalah 0,03gram didapat pada waktu perendaman $18 \mathrm{jam}$, perbandingan 2 didapatkan hasil material hilang terbesar didapatkan pada waktu perendaman 0,04gram didapatkan pada waktu perendaman 18 jam, perbandingan 3 didapatkan hasil material hilang terbesar didapatkan pada waktu perendaman 0,15 gram didapatkan pada waktu perendaman 18 jam, perbandingan 4 didapatkan hasil material hilang terbesar didapatkan pada waktu perendaman 0,07 gram didapatkan pada waktu perendaman 18 jam, perbandingan 5 didapatkan hasil material hilang terbesar didapatkan pada waktu perendaman 0,26 gram didapatkan pada waktu perendaman 18 jam. Dari semua perlakuan perendaman terdapat trendline bahwa semakin lama perendaman maka akan semakin banyak material yang hilang. Terdapat trendline yang sangat menonjol pada perbandingan 5 dengan perbandingan antara $\mathrm{HaCl}$ dan Copper Sulphate 1 berbanding 3 .

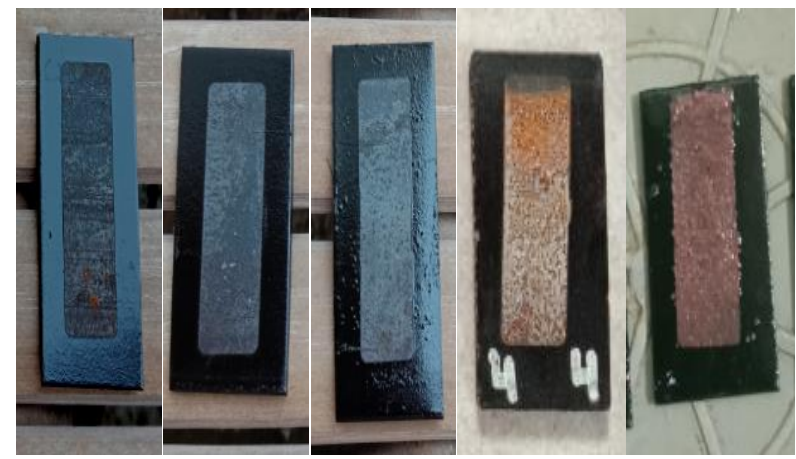
(a)
(b)
(c)
(d)
(e)

Gambar 3, Hasil Visual Spesimen setelah perendaman a) Spesimen uji 1, b) Spesimen uji 2

c) Spesimen uji 3 , d) Spesimen uji4, e) Spesimen uji 5 
Pada Gambar 3, menunjukkan hasil akhir spesimen yang telah dilakukan perendaman dengan larutan $\mathrm{NaCl}$ dan Cooper Sulphate. Terlihat bahwa di setiap perlakuan terlihat adanya pengikisan walaupun secara visual ada yang tampak dan ada yang samar. Dari setiap perlakuan memperlihatkan hasil bahwa semakin besar perbandingan baik $\mathrm{NaCl}$ maupun Cooper Sulphate semakin tampak pengikisan yang terlihat. Dan yang paling tampak secara visual adalah pada perbandingan 5 yaitu $\mathrm{NaCl}$ : Copper Sulphate dengan perbandingan 1:3.

Tetapi antara perbandingan 4 dan perbandingan 5 terdapat perbedaan yaitu pada perbandingan 4 terlihat permukaan lebih halus dari pada perbandingan 5 .

\section{KESIMPULAN}

Dari Penelitian ini , bisa di ambil kesimpulan mengenai pengaruh perbandingan massa antara $\mathrm{NaCl}$ dengan Cooper Sulphate dan waktu perendaman terhadap material hilang pada logam Mild Steel sebagai berikut :

1. Material yang hilang akibat perendaman pada larutan akan semakin banyak bila perbandingan masa Cooper Sulphate semakin besar.

2. Secara Visual kekasaran permukaan material yang dikenai perlakuan dimana perbandingan Cooper Sulphate lebih besar terlihat lebih kasar di banding dengan yang lainnya.

\section{REFERENSI}

[1] Sasmita, D. (2017). Pengaruh suhu dan waktu pelapisan tembaga pada baja karbon rendah secara elektroplating terhadap korosi. EKSAKTA, 2, 61-67.

[2] Bahri, S. (2007). Penghambatan korosi baja beton dalam larutan garam dan asam dengan 